\title{
Heart rupture as a first symptom of acute coronary syndrome
}

Pęknięcie serca pierwszym objawem ostrego zespołu wieńcowego

\author{
Aneta I. Gziut', Piotr Suwalski ${ }^{2}$, Joanna Latek ${ }^{1}$, Robert J. Gil', Kazimierz Suwalski ${ }^{2}$ \\ 1Department of Invasive Cardiology, Central Clinical Hospital of the Ministry of Internal Affairs, Warsaw, Poland \\ 2Department of Cardiosurgery, Central Clinical Hospital of the Ministry of Internal Affairs, Warsaw, Poland
}

Postep Kardiol Inter 2012; 8, 3 (29): 253-257

DOI: 10.5114/pwki.2012.30407

\begin{abstract}
A 67-year-old woman with symptoms of cardiogenic shock is reported. Heart rupture as a complication of acute coronary syndrome was diagnosed. Cardiorrhaphy was performed. In the next stage coronary angiography was performed. Subtotal stenosis of a small marginal branch was responsible for this incident.
\end{abstract}

Key words: heart rupture, acute coronary syndrome

\section{Streszczenie}

Przedstawiono przypadek 67-letniej chorej przyjętej z wstępnym rozpoznaniem wstrząsu kardiogennego. Rozpoznano pęknięcie serca jako powikłanie ostrego zespołu wieńcowego. Kardiochirurgicznie zszyto uszkodzony mięsień sercowy. W kolejnym etapie wykonano koronarografię. Ustalono, że za zaistniały epizod odpowiada subtotalnie zwężona mała gałąź marginalna.

Słowa kluczowe: pęknięcie serca, ostry zespół wieńcowy

\section{Case report}

A female patient was brought to the hospital's Emergency Department (ED) by an ambulance after losing consciousness, preceded by anginal pain (tightness in the chest) radiating to the jaw. Approximately 5 days before the presentation, the patient suffered from a nonspecific pain felt in the throat region, and mild shortness of breath, which she thought were signs of infection. Until the hospitalization, the patient was treated only for hypertension.

At admission to the ED (11:01), the patient was in a moderate general condition (blood pressure 70/40 mm Hg, HR 117/min, oxygen saturation 100\%). She denied stenocardia, dyspnoea, and reported only thoracic spine pain. In laboratory tests performed at admission, the following abnormal results were found: elevated levels of cardiac necrosis markers (CK 181 IU/l, CKMB 32 IU/I, Tnl 8.308 ng/l), elevated inflammation markers (WBC 14000, CRP 107 mg/l). Additionally, anaemia (RBC 4.83 million, haemoglobin $10.2 \mathrm{~g} / \mathrm{dl}$, haematocrit 34.7\%) and hypokalaemia (3.09 $\mathrm{mmol} / \mathrm{l})$ were found. An electrocardiography (ECG) made in the emergency department revealed upsloping ST-segment elevation of $1 \mathrm{~mm}$ in leads I and aVL, concave ST-segment elevation of $0.5 \mathrm{~mm}$ in leads II, III and aVF, and ST-segment depression of $1 \mathrm{~mm}$ in leads $V_{1}-V_{3}$. The echocardiographic study performed in the ED revealed no left ventricular systolic dysfunction. Pericardial effusion (up to $23 \mathrm{~mm}$ next to the diaphragmatic part of the right ventricle) and a large amount (up to $12 \mathrm{~mm}$ ) of fibrin were found. Additionally, signs of right ventricular overload were observed [dilated inferior vena cava $(30 \mathrm{~mm}$ ) with a limited respiratory variation]. Aortic dissection was excluded on the basis of a computed tomography scan of the chest. For further diagnostic procedures and treatment, the patient was transferred to the Cardiac Intensive Care Unit.

At admission to the Cardiac Intensive Care Unit (14:51), the patient's general condition was described as severe.

Corresponding author/Adres do korespondencji:

Aneta I. Gziut, Departament of Invasive Cardiology, Central Clinical Hospital of the Ministra of Internal Affairs, 137 Wołoska, 02-507 Warsaw, Poland, e-mail: anetagziut@poczta.onet.pl

Praca wpłynęła: 6.08.2012, przyjęta do druku: 23.08.2012. 
Physical examination revealed stasis in the pulmonary circulation (Killip class II), jugular vein congestion, blood pressure $80 / 40$ mm Hg, HR 70/min. Laboratory tests revealed a significant anaemia (RBC 3.39 million, haemoglobin $7.8 \mathrm{~g} / \mathrm{dl}$, haematocrit $26.7 \%$ ), and decreasing levels of cardiac necrosis markers (CK 119 IU/I, CKMB 32 IU/I, TnI 5.761 $\mathrm{ng} / \mathrm{l})$. An ECG revealed negative T-waves in leads I, aVL, $V_{1-3}$, and ST-segment depression of $1 \mathrm{~mm}$ in leads $V_{1-3}$. Initially, the patient was referred for urgent coronary angiography. During the preparation of the patient for the study, a sudden cardiac arrest occurred. Resuscitation procedures were undertaken (short external cardiac massage, ventilation with the Ambu bag). A return of patient's circulatory and respiratory function was achieved. The echocardiography showed signs of cardiac tamponade (increased amount of pericardial effusion, compression of the right ventricle and atrium).

The patient was urgently transferred to the operating theatre of the Department of Cardiac Surgery. During the preparation of the patient for surgery, the patient again experienced cardiac arrest (electromechanical dissociation). The resuscitation procedures were continued. The chest was opened immediately through a longitudinal sternotomy. After the incision of the pericardium, more than $600 \mathrm{ml}$ of partially clotted blood was evacuated (blood flow under pressure). Signs of inferoposterior wall myocardial infarction were seen macroscopically. Within this area, two sites of myocardial rupture were seen. The sites were sutured. Additionally, considering the bleeding from the tissue surrounding the rupture sites and the myocardial infarction zone, the Mikulicz surgical towels were placed inside the pericardial sac. After the bleeding was limited, they were removed, and the myocardial zone was wrapped around with absorbable haemostatic material. Thereafter,

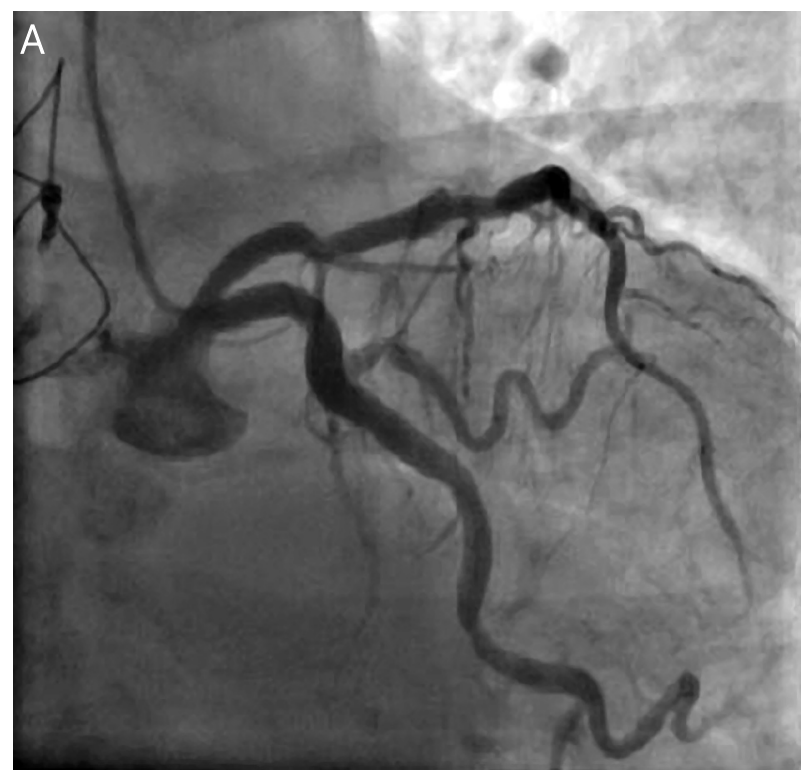

Fig. 1 A-B. Angiogram of left coronary artery Ryc. 1 A-B. Angiografia lewej tętnicy wieńcowej drainage tubes and temporary epicardial wire electrodes were placed, and the chest was closed. The patient was transferred in a stable condition to the Intensive Postoperative Care Unit of the Department of Cardiac Surgery. After about an hour after the surgery, the patient was extubated. After the waking up, the patient was in full verbal and logical contact, with no neurological disorders. In the third day after the surgery, the patient underwent a control echocardiographic examination. It revealed wall motion abnormalities within the mid and apical segment of the laterobasal wall. No significant amount of pericardial effusion was found. During the consultation of cardiologists and cardiac surgeons, the patient was scheduled for coronary angiography. The procedure was scheduled at least 14 days after surgery. The patients received aspirin, bisoprolol, sartan. In the $8^{\text {th }}$ day after surgery, the patient was discharged from the Department of Cardiac Surgery.

At admission to the Department of Invasive Cardiology, the patient was in a good condition (blood pressure 145/85 mm Hg, heart rate 90/min) and denied stenocardia, shortness of breath, reduced exercise capacity, and the occurrence of arrhythmias. An ECG revealed negative T-waves in leads I, II, aVL, aVF and $\mathrm{V}_{5-6}$. Echocardiography showed hypokinesis of the mid and apical segments of the inferior wall, and ejection fraction of $55 \%$. Coronary angiography revealed (Figures 1, 2) 50\% stenosis in the distal segment of the circumflex branch spreading to the ostium of the subtotally occluded second marginal branch. Additionally, the study revealed intermediate (40-50\%) stenosis in the proximal segment of the left anterior descending artery, and the distal segment of the right coronary artery. The proximal and mid segments of the right coronary artery showed aneurysmal enlargement, in which there was turbulent flow of a contrast

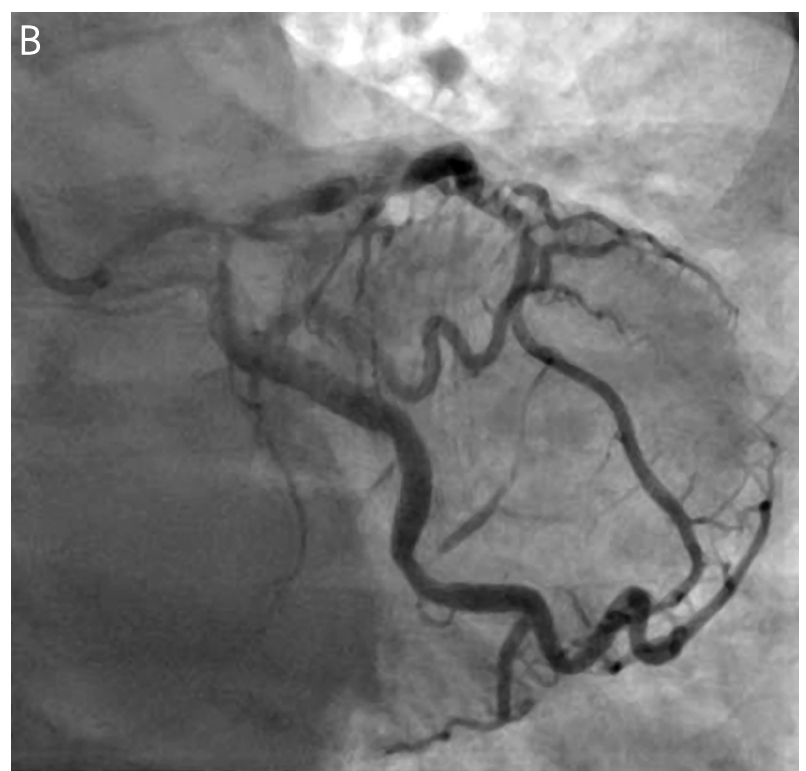


medium. Slow flow and residual contrast medium were also observed in the left anterior descending artery. Because of the small diameter of the vessel with significant stenosis (the marginal branch), the patient was qualified for conservative treatment. Given the abnormal flow in the coronary arteries, we decided to use clopidogrel, statin, eplerenone, and an increased dose of aspirin. In addition, we increased the dose of $\beta$-blocker and sartan. The patient was discharged home in a good condition with a recommendation of continuous outpatient cardiology care.

\section{Discussion}

One of the most dangerous complications that can occur in patients with acute coronary syndromes is a heart rupture (HR). According to the classification by Becker et al., two types are distinguished: free wall rupture, and interventricular septum rupture [1]. The classification of types of $H R$ is shown in Figure 3.

In the era of treatment of myocardial infarction with percutaneous revascularization, $\mathrm{HR}$ is no longer a common complication of an acute coronary syndrome. However, in the so-called "pre-reperfusion" era, this complication occurred in up to $6 \%$ of patients with acute coronary syndromes. It was associated with in-hospital mortality of $30 \%$. With the development of pharmacological treatment (thrombolysis, antiplatelet drugs), and other treat-

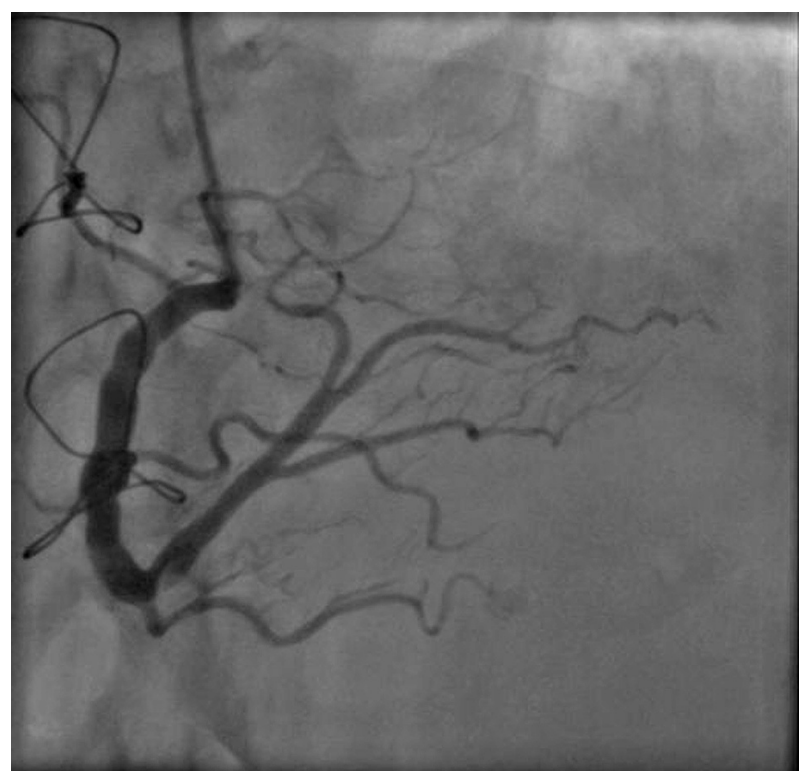

Fig. 2. Angiogram of right coronary artery

Ryc. 2. Angiografia prawej tętnicy wieńcowej

ment methods (percutaneous reperfusion), the incidence of HR significantly decreased. In a retrospective observation, Figueras et al. found that the incidence of HR was reduced from $6 \%$ in the period before the year 1982 to $3.2 \%$ in the years 2001-2006 [2]. However, in the population from the GRACE study, the incidence of HR was

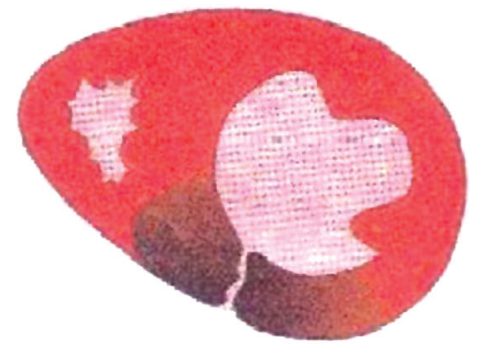

Type 1

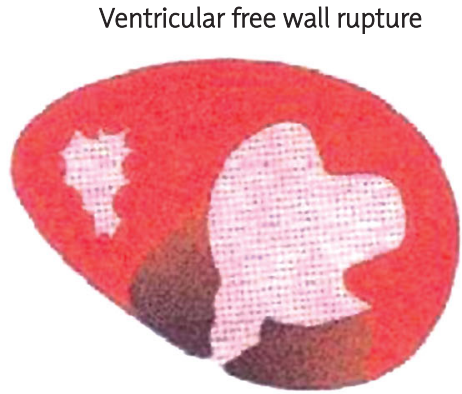

Type 2

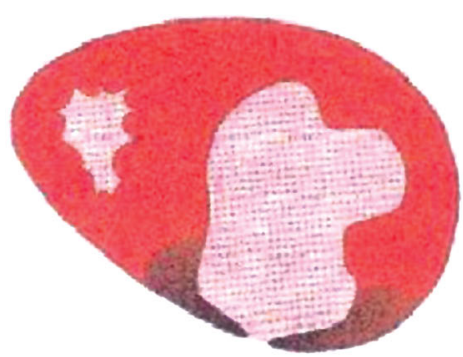

Type 3

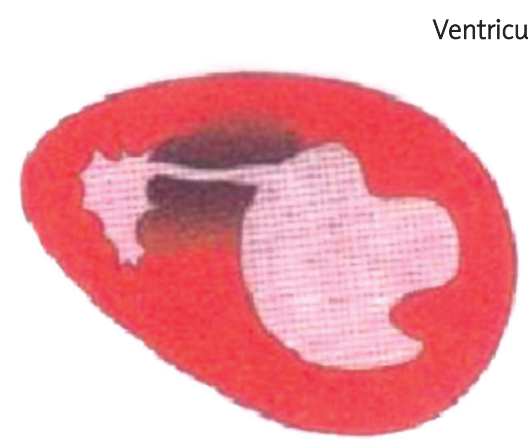

Simple

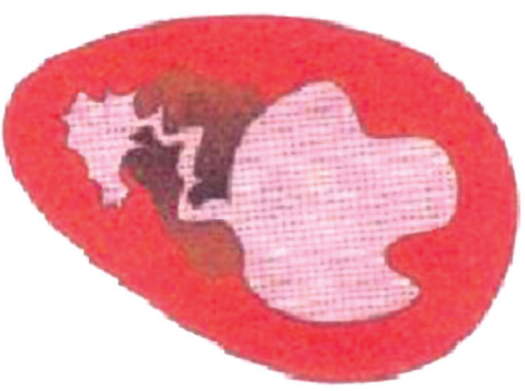

Complex

Fig. 3. Classification of heart rupture according to Becker

Ryc. 3. Podziat pęknięcia mięśnia serca według klasyfikacji Beckera 
Table 1. Incidence of heart rupture related to treatment strategy

Tabela 1. Częstość występowania pęknięcia serca w zależności od strategii leczenia

\begin{tabular}{lcc} 
Variable & & Incidence of HR (\%) \\
\hline Fibrinolysis (-), $\mathrm{PCl}(-)$ & & 1.2 \\
\hline $\mathrm{PCl}$ & & 0.7 \\
\hline Fibrinolysis & 1.1 \\
\hline $\begin{array}{l}\text { Time from onset of symptoms } \\
\text { to fibrinolysis [h] }\end{array}$ & $0-2$ & 0.7 \\
\cline { 2 - 3 } & $2-4$ & 1 \\
\cline { 2 - 3 } & $4-12$ & 1.7 \\
\cline { 2 - 3 } & $>12$ & 2.2
\end{tabular}

approximately $1 \%$ [3]. Interestingly, it was found that its incidence depends on the type of acute coronary syndrome (0.9\% in STEMI, $0.17 \%$ in NSTEMI, and $0.25 \%$ in unstable angina). However, despite the progress of diagnostic and surgical techniques, in-hospital mortality $(5.6 \%)$ is high both in patients with cardiac free wall rupture $(80 \%)$ and those with septum rupture (41\%). In the multivariate analysis, the independent predictors of HR were STEMI, older age, female gender, previous stroke, tachycardia, hypotension, elevated markers of cardiac necrosis, and a high score on the GRACE Scale. In contrast, previous myocardial infarction and the use of $\beta$-blockers in the first $24 \mathrm{~h}$ after the onset of myocardial infarction were associated with a risk reduction [3].

When one analyses the risk factors for $\mathrm{HR}$, it is worth considering the presence of coronary collateral circulation, the impact of fibrinolysis, and the time from the onset of symptoms to fibrinolysis. Undoubtedly, heart rupture is affected by a total occlusion of a coronary artery, without concomitant collateral circulation. This explains why HR is more frequent in patients with first myocardial infarction (especially STEMI). Therefore, it was thought that reperfusion of the infarct-related artery would result in reduction of this complication. However, the results of conducted studies were surprising (Table 1) [3]. They confirmed that early thrombolysis and reperfusion have a protective effect. However, delayed reperfusion is associated with an increased incidence of intramyocardial bleeding, and consequently with an increased risk of heart rupture. In addition, inadequate myocardial reperfusion occurs - increased blood flow in the already irreversibly damaged muscle.

Primary coronary angioplasty leads to restoration of coronary blood circulation more often than fibrinolysis, and the risk of bleeding is lower. This explains why mechanical complications occur less frequently after $\mathrm{PCl}$ than after fibrinolysis. However, if $\mathrm{PCl}$ is unsuccessful, the risk of $H R$ increases.

Prompt diagnosis in patients with suspected cardiac free wall rupture and acute tamponade of unknown origin should lead to direct transfer of a patient to the operating room [4]. In such cases, performing diagnostic studies oth- er than echocardiography (e.g. coronary angiography) is not recommended. The time to open the pericardial sac should be reduced to the necessary minimum. For this reason, only in centres with cardiology and cardiac surgery facilities are these patients likely to be effectively treated. In severe tamponade, pericardiocentesis can be the "last chance" manoeuvre before transport to the operating room. The use of the intra-aortic balloon pump (IABP) depends on the patient's condition, and can help in extreme cases. However, note that the use of IABP causes a significant delay of cardiac surgery procedures, and IABP does not affect the mechanism of tamponade.

Several treatment methods of acute free wall cardiac rupture are described in the literature [4-9]. However, because they are mainly reports of single cases, the decision about the choice of method depends on the experience of a cardiac surgeon. Undoubtedly, the following factors have an influence on the choice of type of surgery: patient's haemodynamic status, location of bleeding, the extent of myocardial infarction, and the presence of other comorbidities (such as ventricular septal defect). The available data indicate that in order to obtain significant reduction of bleeding, cardiopulmonary bypass should be avoided, and surgical suturing should be limited to the minimum. It is also worth using other haemostatic methods. All sutures should be strengthened with the use of a felt or pericardial pad. In the "classical" method, continuous horizontal "mattress" sutures on two felt strips are used. An important limitation of this method is the fragility of the heart muscle tissue [4]. The removal of necrotic tissue from the ventricle wall, and the use of single horizontal "mattress" sutures with felt or Dacron patches, reinforced by a second layer of monofilament sutures, have been reported primarily in patients undergoing closure of septal rupture $[8,9]$. Núñez et al. described a method based on suturing of the rupture site with single horizontal sutures with felt or Dacron pads and subsequent suturing to the "healthy" epicardium (with a wide margin of healthy tissue) with a Teflon patch, bovine pericardium or the patient's own pericardium [7]. The researchers emphasized particularly good haemostatic properties of this method, especially when combined with the use of biological and non-biological tissue adhesives [9]. The reports of the successful use of fast-drying glues (cyanoacrylate adhesives), well known to all as the glues advertised as necessities in a household, together with felt or Teflon patches, are very interesting $[8,9]$.

Although the incidence of HR is currently negligible, the case of the present patient best shows that this problem still occurs. Undoubtedly, it is not typical. The present patient interpreted her symptoms as a respiratory infection and therefore the myocardial infarction was not diagnosed. It was a coincidence that a free wall heart rupture, and symptoms of tamponade, occurred in the hospital, which enabled the patient's survival. However, we have to admit that for the entire cardiological and cardiac surgery 
team caring for the patient, the result of coronary angiography was surprising. We expected HR to have been caused by an occlusion of an artery with a much higher diameter.

\section{References}

1. Becker AE, van Mantgem JP. Cardiac tamponade. A study of 50 hearts. Eur J Cardiol 1975; 3: 349-358.

2. Figueras J, Alcalde O, Barrabes JA, et al. Changes in hospital mortality rates in 425 patients with acute ST-elevation myocardial infarction and cardiac rupture over a 30-years period. Circulation 2008; 118: 2783-9.

3. Lopez-Sendon J, Gurfinkel EP, Lopez de Sa E, et al. For the Global Registry of Acute Coronary Events (GRACE) Investigators: factors related to heart rupture in acute coronary syndromes in the Global Registry of Acute Coronary Events. Eur Heart J 2010; 31: 1449-1456.

4. David TE. Surgery for postinfarction rupture of the free wall of the ventricle, in David TE (ed.): Mechanical complications of myocardial infarction. Austin, TX, RG Landes, 1993; 142.

5. Hatcher CR Jr, Mansour K, Logan WD Jr, et al. Surgical complications of myocardial infarction. Am Surg 1970; 36: 163.

6. Eisenmann B, Bareiss P, Pacifico AD, et al. Anatomic, clinical, and therapeutic features of acute cardiac rupture. J Thorac Cardiovasc Surg 1978; 76: 78.

7. Núñez L, de la Llana R, López Sendón J, et al. Diagnosis and treatment of subacute free wall ventricular rupture after infarction. Ann Thorac Surg 1982; 35: 525.

8. Padró JM, Mesa J, Silvestre J, et al. Subacute cardiac rupture: repair with a sutureless technique. Ann Thorac Surg 1993; 55: 20.

9. Lachapelle K, deVarennes B, Ergina PL. Sutureless patch technique for postinfarction left ventricular rupture. Ann Thorac Surg 2002; 74: 96 